A revised version of this paper was accepted for publication after the submission of our abstract for the IASC meeting in January 2011. The on-line first version of the article is already available (http://dx.doi.org/10.1016/j. worlddev.2010.09.013). The final version will appear in the March 2011 issue of World Development, volume 39 , no. 3.

\title{
Repertoires of Domination: Decentralization as Process in Botswana and Senegal1
}

\author{
Amy R. Poteete ${ }^{2} \&$ Jesse C. Ribot ${ }^{3}$
}

\begin{abstract}
Decentralization promises to empower local actors, but threatens others with a loss of power. We describe "repertoires of domination" as the set of acts actors perform to defend - or entrench and expand - their positions. We illustrate how repertoires of domination prevent local-level democratization through the decentralization of natural resource management in Botswana and Senegal. The concept of repertoire brings attention to the availability of multiple, substitutable acts of domination that draw upon varied sources of power. Neither decentralization nor democratization can be achieved once and for all. These processes are both advanced and halted through acts of contestation.
\end{abstract}

Key words: decentralization; natural resource management; democratization; Africa; Botswana; Senegal

\footnotetext{
${ }^{1}$ Acknowledgments: We have benefitted from thoughtful comments from Catherine Boone, John Harbeson, Sandra Joireman, Staffan Lindberg, Aurelien Mauxion, Innocent Ndahiriwe, Andrea Nightingale, Hemant Ojha, Leander Schneider, Thomas Sikor, and Peter von Doepp, as well as enriching exchanges during the Workshop on the Workshop IV at Indiana University in June 2009. Thanks for the Government of Botswana's permission to conduct research in the Botswana; financial support from the Fulbright Foundation, the Social Science Research Council, and University of New Orleans; institutional support from the University of Botswana, and help from respondents and friends in Botswana. Sincere thanks to the Dutch Royal Embassy in Dakar, in particular Franke Toornstra, for supporting the research behind the Senegal case study.

2 Concordia University, Montreal.

3 University of Illinois, Urbana-Champaign.
} 


\section{Introduction}

Decentralization promises improvements in efficiency, responsiveness to spatially variable conditions, and greater opportunities for citizen participation and empowerment. In theory, these outcomes hinge on how decentralization alters relations of authority and, especially, the allocation of power to broadly representative and downwardly accountable local actors (Agrawal and Ribot 1999; Blair 2000). To enhance local democracy, decentralization must increase opportunities for local people to participate in binding forms of consultation (representation with accountability) and provide access to significant material resources and decision-making authority. Only then will local actors be transformed from subjects of non-local authority into citizens of a democratic local regime (Ribot 1999a; Mamdani 1996).

Although successes have been documented, instances of local democratic empowerment through decentralization are few and far between (Blair 2000; Crook and Manor 1998; Fung and Wright 2003a; Heller 2001; Ribot 2004). Disappointments with decentralization are often attributed to institutional problems, suggesting that improvements can be gained with greater attention to 'getting the institutions right' (Fung and Wright 2003b; Gibson and Marks 1995; Manor 2004; Wunsch 2001). Multiple case studies tell a different story. Responsibilities of local actors are often increased, while their authority to make significant local decisions is not. Onerous requirements and inadequate finance limit the ability of local actors to exercise new powers that are formally within their reach. Alternatively, reforms devolve meaningful authority to local actors who are not accountable to a broadly defined local community (Ribot 2002; Manor 2004; Larson and Ribot 2007; Ribot et al. 2008; Wittayapak and Vandergeest 2009).

These problems are not simply the products of flawed institutional design. They reflect the political contestation surrounding decentralization programs. Despite public discourses, governments typically do not introduce programs of decentralization with the goal of enhancing democracy. They are typically motivated by other political and economic concerns or crises (Agrawal and Ostrom 2001; Alden Wily and Mbaya 2001; Barrow et al. 2001; Bazaara 2006; O'Neill 2003). Powerful actors resist local empowerment at every step (Ribot and Oyono 2005). While promoting decentralization reforms, central and mid-level actors are also trying to retain powers and limit the competition presented by local authority (Bates 1983; Blaikie 2006; Wunsch 2001). Similarly, local-level officials, traditional leaders, and commercial elites, resist the loss of power to rival local bodies.

That powerful actors (governments, commercial interests, and large development or environment organizations) resist decentralization should be no surprise. Decentralization policies alter institutional arrangements and patterns of control over resources. These changes destabilize authority relations and intensify competition for power. Central actors counteract the loss of powers by blocking the transfer of meaningful powers to local authorities or by only 'transferring' 
powers to local actors they can control. Other agencies, NGOs, and commercial interests gain power by positioning themselves as intermediaries between center and local, while resisting both central oversight and downward accountability. In most decentralization policies, the net result is continued non-local control over all significant local decision-making processes.

Centripetal forces are a constant aspect of decentralization reforms. We show that these forces act in many different ways. In the same place, devolution of some powers may be stymied by arguments that local actors lack the capacity to exercise those powers, while the transfer of another power may be prevented via selective implementation of laws or threats of violence. Across localities, powerful actors may use totally different theatrics to retain power over the same domain, such as the right to commercially exploit forests.

What we call 'repertoires of domination' are sets of acts that those contending for power can perform to establish, defend, entrench, or expand a position of dominance. Repertoires mobilize diverse sources of power, informal as well as formal, social and economic as well as political and administrative. When threatened by decentralization, beneficiaries of the status quo draw on repertoires of domination to defend against losses of authority and access to resources. ${ }^{4}$ Powerful higher-scale or parallel actors (within government or holding 'customary' positions) can substitute performances from their repertoire based on informal social, political, and economic power even if decentralization reduces their formal political or administrative powers. Under these circumstances, decentralization may achieve little by way of local empowerment.

Being able to identify the range of options within a repertoire and the dynamism characteristic of repertoires is crucial for analyzing obstacles to local democratization and strategies for its promotion. Because repertoires encompass a fluid set of performances, efforts to improve the democratizing effects of decentralization by designing responses to single tactics can have limited effects. Rather, greater local empowerment hinges on the introduction and sustenance of countervailing processes that effectively alter relations of authority at the local level as well as between the central government and localities. Countervailing processes promote local democracy to the extent that they improve local representation and encourage the downward accountability of local and higher authorities.

In the next section, we develop the concept of "repertoires of domination" to describe the myriad tactics government officials and non-state actors use to limit meaningful shifts of authority associated with decentralization. Subsequent sections illustrate the interactions between repertoires of domination and

\footnotetext{
${ }^{4}$ Ribot and Oyono (2005) used the term 'resistance' to describe the acts of powerful actors against decentralization. In this paper we chose to use the language of 'domination' to avoid any confusion with the common usage of the term 'resistance' to refer to the actions of the poor against domination by the powerful.
} 
decentralization policies related to wildlife management in Botswana and forestry management in Senegal, where powerful actors have stymied the emergence of downwardly accountable legitimate local authority, as well as democratic local practice. The specific repertoires, or sets of routine claim-making actions, differ across the two cases and across sets of actors within each case, but, they activate an overlapping set of processes that short-circuit the consolidation of local democracy in both cases. We conclude by drawing out the implications of repertoires of domination for the conceptualization of power, the processes of decentralization and recentralization, and the prospects for political change.

\section{Repertoires of Domination: Turning Resistance on its Head}

Resistance to the claims of others-for the purposes of domination or self protection-is a form of claim making. We define "repertoires of domination" as the sets of routine claim-making actions available to actors as they seek to gain, expand, or defend positions of dominance vis-à-vis particular types of other actors. ${ }^{5}$ They represent a sub-set of repertoires of contention (Tilly 1978, 2006, 2008; see also Tarrow 2008) defined by the goal of domination. 6

Like other types of repertoires, repertoires of domination vary across settings and relationships and are influenced by familiarity, socially constructed meanings and norms of appropriate behavior in particular types of relationships, and strategic considerations. They involve performances in diverse realms of social interaction and draw upon diverse resources such as capital and market access, social identity and status, formal and informal authority, technology, and knowledge. We expect repertoires of domination to include many solo and small ensemble performances in relatively intimate settings, including coded threats, bribes, coercion, and collusion. Although these actions involve few actors and occur in less-public settings, they are still claim-making performances.

We introduce the concept of 'repertoires of domination' to train interest on the multiple ways in which powerful actors gain, build and maintain positions of dominance. Conceptualization of claim-making in terms of performances and repertoires draws attention to the coexistence of routine ways of doing things with creativity, improvisation, and variability in the quality of performances (see also Alexander and Mast 2006). Actors compete to define their own role and that of allies and rivals. They also take actions to display or claim power and highlight the vulnerability or dependency of rivals. Some performances appeal to norms of morality while others showcase strength in markets, politics, or the administrative

\footnotetext{
${ }^{5}$ We are not claiming that dominance is actually achieved, nor that any single dominant actor exists. Contestation for dominance is an ongoing process.

${ }^{6}$ In principle, repertoires of contention encompass claim-making by any set of actors, whether within the state or outside, whether powerful or marginalized. Nonetheless, most applications of the concept focus on the repertoires of actors mobilizing to challenge the status quo. See also Scott's (1985) discussion of "everyday forms of resistance". But see Peluso's (1992) references to "repertoires of control" and Salvatore's (2002) conceptualization of "repertoires of coercion."
} 
structure. Repeatedly, we see actors adopting one role for one audience, only to present an entirely different image for another audience.

Multiple performances are possible in part because there are multiple sources and forms of power: political, economic, discursive, coercive, symbolic or real violence, or the power to control and manufacture knowledge. Formal and informal powers often coexist and reinforce each other, but the correspondence is not perfect. Actors who lack formal rights, for example, can control informal sources of power, whether material, discursive, or rooted in violence. Actors hold bundles of power, which they mobilize to gain, maintain, or control access to tangible and intangible things (Ribot and Peluso 2003), including more power. Repertoires of domination offer many different performances because actors can combine and recombine their powers in varied ways, depending on the situation.

This understanding of power and its use implies that the state is not the only or even the most important source of power and regulation (Mitchell 1991). ${ }^{7}$ Power also resides in non-state public authorities - what Lund (2006) refers to as "twilight institutions" - and operates outside of and across particular organizations (Foucault 1976, 1979). Power may be manifest at least as much in the "leakages" across boundaries - organizational, spatial, sectoral, temporal - as in the boundaries themselves (compare Rajchman 2000).

These understandings of power have several implications. We emphasize three here. First, if power takes multiple forms and is not easily contained, it must be understood as mobilized (or perhaps produced) through practice. Second, manifestations of power are not static; they are subject to improvisation and transposition. Third, if power is not monopolized by state institutions, then changes in state institutions, including those resulting from decentralization policies, influence some but not all strands of power. Hence, the forms and uses of power must be observed in practice, these practices must be followed as they shift and reconfigure, and formal policy must be viewed as affecting only some of the powers of actors who regulate and of those regulated.

We argue that decentralization rarely generates democratization because powerful actors are able to use repertoires of domination effectively to maintain or strengthen their positions-circumventing or neutralizing formal policy change. Because repertoires involve actions in multiple realms of social interaction and draw on a variety of socio-political, material, and normative resources, they represent sources of flexibility and creativity in the exercise of power. Through a whole array of acts by powerful actors within and outside of the state, decentralization reforms are constrained and reworked. In the next section we illustrate how repertoires of domination were deployed in response to the decentralization of natural resources in Botswana and Senegal.

\footnotetext{
${ }^{7}$ Indeed, it challenges the sharpness of the boundary between state and society.
} 


\section{Decentralization and Local Authority in Botswana and Senegal}

We are concerned with programs that decentralize control over decisions and revenue streams associated with local natural resources. Local control over decisions and sources of revenue should increase the autonomy of local communities from central government and other powerful actors. Yet, as with other forms of decentralization, most programs for decentralized natural resource management have had little effect on local power (Hulme and Murphree 2001; Alden Wily and Mbaya 2001; Barrow et al. 2001; Larson and Ribot 2007; Ribot et al. 2006; Wittayapak and Vandergeest 2009).

We consider two examples: Botswana's Community Based Natural Resource Management (CBNRM) program for wildlife management and the decentralization of forestry management in Senegal. While we find flawed institutional arrangements in both countries, repertoires of domination present more important obstacles to both local empowerment and democratization. In both cases, actors threatened by decentralization drew upon defensive repertoires to fetter the transfer of significant powers over natural resources to local authorities. We describe the origins and main features of the sector-specific decentralization policy or program for each case. We then illustrate how repertoires of domination are performed to slow, halt, or reverse the consolidation of local authority and processes of democratization. Although the specific practices are diverse and rooted in local contexts and relationships, an overlapping set of mechanisms is at work in the two cases. These mechanisms include (de)legitimation; misrepresentation and obfuscation; the fostering of dependency; threats, bribes, sabotage, and coercion; cooptation, fragmentation, and isolation of rivals; coalition-building and collusion; and deflection of attention. We begin with Botswana, and then turn to Senegal.

\section{Botswana: Decentralization of Wildlife Management}

In the late 1980s, the US Agency for International Development (USAID) encouraged Botswana to decentralize wildlife management to address poaching, antagonistic relations with residents of wildlife areas, and other management problems (Blaikie 2006; Taylor 2002). USAID argued that rural residents would be more supportive of conservation measures if they received tangible benefits from wildlife. The Community Based Natural Resource Management (CBNRM) program was launched as a pilot project in the Chobe Enclave in 1989 and then spread to other areas. Many of the most wildlife-rich areas in Botswana are now under community management.

This section first describes Botswana's generally centralized approach to wildlife management and introduces the CBNRM program. Between 1989 and 2007, Botswana's CBNRM program conferred significant control over wildlife revenues to small-scale communities in selected wildlife-rich areas. The enhanced role for local communities threatened the beneficiaries of centralized management. The case of Khwai illustrates the myriad tactics by which commercial interests, 
district-level agencies, and national politicians sought to limit the autonomy of local residents. Similar repertoires of domination played out in many other communities and contributed to the partial recentralization of wildlife management in the CBNRM policy of 2007.

\section{Centralized Conservation and High-End Tourism}

Wildlife management in Botswana has been highly centralized and exclusionary. Policy and regulations prioritize environmental conservation and, increasingly, tourism. Virtually non-existent in the late 1980s, international tourism burgeoned in the 1990s to become Botswana's second largest economic sector (ARCA Consulting 2000; Mbaiwa 2005a; Stevens and Jansen 2002).

Justified by the need to balance tourism with conservation, Botswana promotes high-cost and low-volume tourism by charging relatively high fees for entry into protected areas and regulating safari tour operators. Tour operators must acquire a license to offer tourism services, a commercial lease from an elected districtlevel Land Board for the use of land for campsites and lodges, and permits from the wildlife department to enter protected areas or hunt. The wildlife department sets an annual quota for the maximum off-take for each species; each safari company purchases licenses that specify the number and species of the animals that its clients may hunt. These regulations and associated fees represent significant barriers to entry into the tourism industry. Although tour operators complain about excessive regulation, they also benefit from restrictions on competition, especially the near elimination of competition from companies that target the low end of the market.

These policies, regulations, and practices favor the Land Boards, the wildlife department and high-end tour operations but impose high costs on rural residents. Exclusionary protected areas reduce the land available for residences and agriculture. Since the mid-1980s, livestock production has been banned even in Wildlife Management Areas (WMAs) outside the parks and reserves (Republic of Botswana 1986). ${ }^{8}$ Quotas and restrictions on techniques used in subsistence hunting have also tightened over the same period (Bolaane 2004; Taylor 2002). Unlicensed subsistence hunters are treated as poachers and subjected to stiff penalties and abusive treatment (Bolaane 2004; Mbaiwa 2005b; Taylor 2000). Residents of wilderness areas complain bitterly about the lack of local benefits from tourism and the limits placed on their livelihood strategies in the name of conservation. According to their popular refrain, the government only cares about the welfare of wild animals.

\section{Selective Decentralization of Wildlife Management}

CBNRM attempted to assuage this built-up resentment. In areas that the wildlife department has designated for community management, CBNRM allows residents to make decisions about natural-resource management and tourism

${ }^{8}$ WMAs encompass more than $39 \%$ of the country's land area (Swatuk, 2005: 102) 
activities. To take advantage of CBNRM, residents of an eligible area must form a legally registered community-based organization (CBO). This section describes the process for forming $\mathrm{CBO}$ and then outlines the powers conferred upon them by CBNRM.

CBOs are special-purpose organizations that encompass one or a few villages. $A$ district-level Technical Advisory Committee (TAC) oversees the formation of CBOs through a series of community meetings, culminating in non-partisan elections (Cassidy 2000; Thakadu 2005). Elections to the CBOs are not closely regulated (compare Manor 2004). There is no legal definition of local community membership, ${ }^{9}$ no list of eligible voters, and no procedures are in place to ensure the confidentially of the vote. Membership criteria must be specified, however, in the $\mathrm{CBO}$ constitution. The TAC encourages CBOs to adopt residency based membership criteria and vetoes formulations that it finds questionable.

Nonetheless, the standing of residents who are perceived as newcomers and those who work elsewhere is not always resolved. The veto power of the TAC, ambiguities about membership, and weak regulation of elections weaken incentives for downward accountability.

CBNRM empowers legally registered CBOs to receive rights to access and manage land from the Land Board and rights over particular uses of wildlife resources from the wildlife department (e.g., photo safaris, hunting quotas). A CBO may choose to manage its area directly, sell or auction access and use rights to members or non-members, or form a joint venture partnership with a safari operator to manage and market its wildlife resources. Joint venture partnerships provide small-scale communities with greater access to international tourist markets and are encouraged by government officials. Nonetheless, CBOs can decide which safari companies, if any, can operate in their areas and on what terms. Negotiations with tour operators yield a variety of concessions for CBOs, including employment opportunities for members, training and educational opportunities, targeted investments in infrastructure and local businesses, and assistance with day-to-day challenges (e.g., ploughing, transportation related to funerals). Some CBOs run smaller-scale tourism initiatives, such as cultural activities, hiking trails, and camp sites (Flyman 2001; Gujadhur and Motshubi 2001).

From 1989 until the adoption of the 2007 policy, revenues generated from tourism activities in community-managed areas flowed directly to the CBOs. CBOs have considerable discretion over the allocation of these revenues. Their investments in water development, small businesses, and community services reflected locally set priorities that often would not have been met otherwise. The CBNRM policy of 2007 affirmed the possibilities for community management of wildlife through leases from the Land Boards and the allocation of hunting quotas

\footnotetext{
${ }^{9}$ In everyday practice, community may refer to shared ancestral roots, ethnicity, residence, and recurring use of the natural resource base. These sorts of ambiguities surrounding the definition of community are more general (Agrawal and Gibson 1999).
} 
from the wildlife department. But it also reduced the CBOs' share of revenues generated from wildlife resources in their areas to 35 per cent and diverted the other 65 per cent into a National Environment Fund for disbursement as grants to CBOs throughout the country (Republic of Botswana 2007). This replacement of more or less unconditional revenue flows with conditional grants represents an important if partial re-centralization.

Although the 2007 policy marks a sharp change of direction in some respects, it also institutionalizes processes that had been underway for years. A dispute among the Land Board, a CBO, a safari company, senior government officials and politicians, underlines the array of actors aligned against the devolution of authority to local communities, the depth of the repertoire available to each type of actor, and the manifold ways that particular mechanisms and processes of capture or recapture may be activated. The narrative draws out and juxtaposes competing perspectives, images and interpretations, and sources of power.

\section{Khwai and the Tsaro Lodge}

The village of Khwai was created for people displaced by the creation of the Moremi Game Reserve in 1963. The wildlife department later designated Khwai and the surrounding area as a Wildlife Management Area (WMA) and several companies constructed safari lodges in the area on land leased from the Land Board. There have long been hostile relations between the residents of Khwai, government agencies, and the safari companies (Bolaane 2004; Mbaiwa 2005b; Taylor 2000). Residents never accepted the Reserve, the restrictions on natural resource use associated with the area's status as a WMA, or the presence of safari companies. In part to defuse this situation, the government decided in 1995 to transfer a wilderness area to Khwai as part of its expansion of CBNRM; lodges in the area were to be transferred from safari companies to Khwai upon expiration of existing leases.

Khwai initially formed the Khwai Development Trust (KDT) as a CBO that limited community membership to BaSarwa, the ethnic label for the people who had been evicted upon the creation of the Moremi Game Reserve and the most marginalized ethnic category in Botswana. ${ }^{10}$ Residents of Khwai cast themselves as victims of dispossession with historical rights that precede any government policy. They defined their relationship with the government as one of negotiation in which the terms of government policy held no special status.

Government officials posed in the role of neutral agents charged with the implementation of policies and enforcement of regulations to which Khwai, like all other communities, must conform. Officials resisted the autonomy claimed by Khwai, insisting that they were simply guarding against discrimination, poor business practices, and violations of procedures. In their role of defenders against ethnic discrimination, the Land Board and the wildlife department refused

\footnotetext{
10 The BaSarwa are also known as San. Although widely referred to as an ethnic category, the term encompasses a variety of mutually incomprehensible language groups.
} 
to transfer management rights until KDT adopted an ethnically neutral constitution (Bolaane 2004; Mbaiwa 2005b). The government's stance denied Khwai's role as a victim of historical displacement and discrimination, its claim to prior rights based on historical presence, or the possibility that formally nondiscriminatory arrangements might favor powerful non-local actors. ${ }^{11}$

After KDT became operational in 2000, it could not engage in tourism or other commercial activities until the Land Board approved its management plan. Instead of delegating tourism operations to a single company through a joint venture partnership, KDT proposed to manage the area itself and to auction off its wildlife quota animal by animal (Boggs 2004; Mbaiwa 2005b). Official regulations allowed for self-management and auctions, yet the Land Board balked. Posing as a defender of good business practices and enforcer of existing policies and plans, it asked for details and insisted on adherence to a management plan developed for the area before the area's transfer to 'community management'.12 The Land Board eventually allowed KDT to conduct an auction in 2000, but continued to press for more familiar arrangements. Safari companies disliked the animal-by-animal auction and lowered their bids after the first year; by 2002, KDT agreed to auction off the entire quota to a single company (Boggs 2004).

KDT had barely begun to exercise its management rights when the lease to a safari company for the Tsaro lodge expired in 2001. Before its expiration, the lease had been transferred several times. Upon approval of each transfer, the Land Board informed the new tenants that the lease would not be renewed when it expired. The lease clearly stated that all physical improvements would be transferred to KDT without compensation at the end of the lease. Nonetheless, when the lease expired, the tenant, Chobe Holdings (Pty) Ltd., lobbied national politicians, the Land Board, and KDT aggressively for an extension and asked for compensation for fixed investments. In addressing national politicians, Chobe Holdings acted surprised and claimed wrongful injury. Chobe challenged the authority of the Land Board by violating the terms of its lease, seeking favoritism, mobilizing political pressure, and threatening to undermine public relations with international tourists. It tried to bully KDT with threats and acts of sabotage.

The company first pressed its case in a letter to a local MP and cabinet member, Jacob Nkate. ${ }^{13}$ First, the company noted that the fifteen-year leases for tourism in community-managed areas are much shorter than the 50 to 99 year leases for other commercial sectors. Second, the company argued that a "benevolent landlord" would give rights of first refusal to the current leaseholder even in the absence of a legal requirement to do so. Third, it noted that it had invested

\footnotetext{
${ }^{11}$ In fact, the CBO chair elected in 2003 is an immigrant from Maun (the district capital) and a moTawana, a member of the locally dominant Tswana group (Mbaiwa 2005b, 151). People must reside in Khwai for 5 years before joining the $\mathrm{CBO}$.

12 Copy of letter dated 17 April 2002 the Land Board Secretary to KDT in TLB/B/11/28 I (65).

13 Copy of letter dated 19 November 2001 found in Tawana Land Board file: TLB/B/11/28 I (42).
} 
substantially in refurbishing the lodge. These appeals - to precedence, informal business norms, and the establishment of informal property claims through investment - attempt to establish the company's role as a responsible business that had been wrongfully injured and thereby legitimize its claim for an extension of its lease.

The company simultaneously pursued other tactics. Its letter to Nkate had dismissed KDT as lacking both the capacity and authority to make decisions. It nonetheless launched negotiations with the CBO in an effort to get partial compensation for fixed improvements. KDT rejected this idea. In its correspondence with government officials, the company portrayed KDT as failing to negotiate sincerely. ${ }^{14}$ From community's perspective, however, KDT had already gone beyond what was required in giving the company a hearing and was under no obligation to accept its proposal.

Chobe Holdings also depicted the Land Board as irresponsible and biased. It argued that the Land Board provided inadequate notice of the lease's impending termination. When a local newspaper published an article on the conflict, the company accused the Land Board of going to the press. ${ }^{15}$ With these complaints, the company suggested that the central government should overrule local authorities because they had discredited themselves. The cabinet suspended the eviction and discussed the matter, but decided to uphold the terms of the lease and proceed with the transfer to KDT. But, while disputing the termination of its lease, Chobe Holdings had continued to book clients. ${ }^{16}$ The company then argued, successfully, for a delay in vacating the premises to avoid disruptions for the tourists. According to the Land Board, Chobe Holdings trashed the premises when leaving in an act of sabotage. ${ }^{17}$ Afterwards, in another letter to Nkate, the company again claimed wrongful injury and demanded compensation for physical improvements on the property. ${ }^{18}$ The central government again backed up the Land Board. ${ }^{19}$

KDT gained management authority over the Tsaro Lodge in January 2002, but needed the Land Board's approval for its new management plan before it could reopen the lodge. By June 2002, the lodge had not yet reopened and lan Khama, then Botswana's vice president, 20 entered the drama as a defender of national interests in keeping tourist facilities operational. Khama suggested that KDT

\footnotetext{
${ }^{14}$ Copy of letter dated 29 November 2001 found in Tawana Land Board file: TLB/B/11/28 I (46).

15 Copy of letter dated 8 December 2001 found in Tawana Land Board file: TBL/B/11/28 I (53).

16 Copy of Savingram dated 25 January 2002, from the Tawana Land Board to the Permanent Secretary of Jacob Nkate's ministry, found in TLB/B/11/28 I (60).

17 A project description from the GEF Small Grants Program (2006) describes the lodge as having been vandalized.

${ }^{18}$ Copy of letter dated 18 February 2002 found in TLB/B/11/28 I (61).

${ }^{19}$ Copy of letter dated 28 February 2002 from the Permanent Secretary of Jacob Nkate's ministry to Chobe Holding (Pty) Ltd in TLB/B/11/28 (63).

${ }^{20}$ Ian Khama became President of Botswana in April 2008.
} 
should partner with Chobe Holdings to manage the lodge and speed its reopening. ${ }^{21}$ In subsequent correspondence with the Land Board, the vice president repeatedly demanded that Chobe Holdings be given right of first refusal before launching an open bidding process for management of the lodge. Despite its unrelenting efforts, Chobe Holdings failed to gain an extension of its lease, compensation for fixed improvements, or priority status in KDT's selection of a joint venture partner. KDT eventually entered a partnership with another company and received a grant from the Global Environment Facility's Small Grants Program in 2007 to refurbish the lodge (GEF Small Grants Program 2006).

\section{Repertoires of Domination in Botswana}

The types of actions observed in the conflicts surrounding Khwai are not particular to either the actors or situation. Similarly situated actors draw from similar repertoires of domination. Like Chobe Holdings, many safari companies complain about the CBOs' limited understanding of business practices, mount legal challenges, threaten to withhold investment in community-managed areas, make moral appeals, discredit local authorities, and lobby national politicians. This conflict and others like it set in motion powerful processes that steadily eroded support for CBNRM. The emphasis on low CBO capacity and the prerogatives of business delegitimized CBNRM. Threats to withhold investment or to sabotage fixed property upon termination of a lease undermined the CBOs' legal rights to choose and change their business partners. Lobbying and legal challenges drew critical attention to specific institutional arrangements. These acts sought to legitimize commercial interests and chip away at CBNRM, element by element.

The Land Board plays the role of a guardian of policies and procedures for land administration, including procedures associated with the transfer of management responsibilities to CBOs. Guardianship has two sides. In its relations with politicians and safari companies, the Land Board poses as a guard against infringements on the rights of CBOs. In its relations with the CBOs, however, the Land Board construes guardianship as supervisory authority. In the Tsaro lodge dispute, the Land Board insisted upon KDT's legal right to develop its own management strategy and choose its own business partners, despite repeated pressure from the vice president, the office of the president, and other upper levels of the government over more than two years. ${ }^{22}$ In internal correspondence, the Land Board repeatedly underlined its own lack of discretionary authority and the risks of a legal challenge if standard procedures for the selection of business partners were not respected.

\footnotetext{
21 Memo dated 5 June 2003 from the Land Board Secretary to the Director of Tourism, in Tawana Land Board file: TLB/B/KDT/11/28 I.

22 The intervention is documented in, for example, the Tawana Land Board file, Maun Div: TLB, File No.: B/11/28, Volume I: Khwai Development Trust: Tsaro Photographic Lodge.
} 
While legal challenges to Land Board decisions are common, ${ }^{23}$ we have seen that the Land Board and other local authorities exercise considerable authority over the CBOs. Some of these interventions may enhance accountability, but others constrain choices related to membership eligibility, management goals, management and marketing strategies, and the allocation of revenues (development goals). In fact, conflicts between KDT and the Land Board over the management plan contributed to the delay in reopening the Tsaro Lodge. Ironically, the vice president pointed to this delay - a product of the Land Board's reticence to grant KDT discretion over management and marketing strategies as a justification for bringing in Chobe Holdings.

The push and pull between CBOs, commercial interests, and district-level officials is part of a larger drama. The vice president's interventions in CBNRM attracted a lot of attention. As a series of draft versions of the CBNRM policy circulated within the government and among stakeholders, many suspected that lan Khama was the main political force pushing for recentralization of wildlife management. Whether true or not, this widespread belief created a sense that CBNRM and the authority of the CBOs were vulnerable. Other politicians expressed their opposition to CBNRM in parliamentary sessions and through the media (Poteete 2009).

The most vocal opposition came from within the government and the ruling Botswana Democratic Party (BDP). Several BDP politicians argued that CBNRM violates a founding political principle, that natural resources should be treated as national resources (Poteete 2009). They attributed the country's relative political cohesion and stability to the government's commitment to managing natural resources for the collective benefit and warned that CBNRM could present a dangerous slippery slope, encouraging mining communities to press for decentralized management of mineral revenues. After passage of the 2007 policy, one BDP parliamentarian complained in a series of newspaper articles that CBNRM violates the principle of natural resources as national resources (Ntuane 2007a, 2007b) - even though the policy represents a recentralization relative to prior practice.

Another line of attack drew attention to management problems within CBOs and conflated mismanagement with corruption. Nearly one-third of the proceedings from the 2003 meeting of the National CBNRM forum, a stakeholder group, address charges of mismanagement and corruption and strategies for addressing these problems; Khwai was presented as a case study (National CBNRM Forum 2003). The Directorate on Corruption and Economic Crime (DCEC) directed a spotlight on these issues by organizing a workshop on CBNRM in 2006 and posting the keynote address on its website (Ramsden 2006). The government-run Botswana Daily News featured articles on charges of corruption within CBOs, including several that focused on KDT (e.g., BOPA

\footnotetext{
${ }^{23}$ Land Boards have faced regular legal challenges to their decisions based on accusations of favoritism or deviations from standard procedures since the establishment of the Land Tribunal in 1997.
} 
2007a, 2007b). Government officials also underlined problems of mismanagement within CBOs during their regular tours of villages. In these performances, the government offered to intervene as a guardian of ordinary people to provide protection against corrupt elites and help build local capacity.

There is evidence of inefficient allocation of funds and weak accounting practices. Undoubtedly, some individuals have taken advantage of the situation. And yet problems of mismanagement are also manufactured. If the CBOs depend on outsiders for technical assistance, it is because the Land Board and the wildlife department require highly technical management plans with complicated procedures that serve no clear purpose relative to stated ecological or social policy goals. Complicated regulations and stipulations require skills local residents lack and thus set the stage for mismanagement. ${ }^{24}$ Charges of mismanagement have also become a cover for discontent over the substantive nature of decisions taken by the CBOs. Perhaps powerful actors simply cannot accept that CBOs could make discretionary choices that differ from their own preferences (Poteete 2009).

CBNRM did transfer large sums of money to CBOs and gave them discretionary authority over those funds, but CBOs faced repeated obstacles to exercising their discretionary authority. National politicians, officials in various agencies, the district councils, traditional authorities, village development committees, and even CBOs in wildlife-poor districts resisted the shifts in power promised by CBNRM. Each drew upon a distinctive repertoire. As we have seen, some acts fostered dependency; others involved obfuscation and misrepresentation, or threats and coercion. And many actors sought to delegitimize CBOs and the whole idea of decentralized natural resource management. Ultimately, the CBOs could not defend themselves against the political pressures for recentralization and redistribution that resulted in the 2007 policy.

\section{Senegal: Decentralization of Forest Management to Rural Councils}

Forest villages in Senegal's Tambacounda Region successfully marketed charcoal in the capital city, Dakar, quintupling their income. This success story, unfortunately, also illustrates how powerful actors succeed in limiting or preventing implementation of progressive decentralization reforms. This section describes Senegal's forestry sector decentralization reform and then tells the story of how development projects helped forest villagers to finally reap a portion of the enormous profits available from their forests. As we will see, resistance from government officials and merchants both delayed and constrained the villagers' realization of their legal rights to engage in charcoal production. We situate this qualified success within the larger story of decentralized forestry in and outside of the protected 'managed' project areas.

\footnotetext{
24 These arrangements also force dependency on external actors and create opportunities for obfuscation and misrepresentation, as officials exercise extra-legal discretion in the name of regulatory authority or supervision.
} 


\section{The forestry sector before decentralization}

Charcoal is the primary cooking fuel in Senegal's cities. Given its high value and its perceived 25 impact on forests, charcoal production is heavily regulated by the Forest Service. Until 1998, the system of forest management was totally centralized-orbiting around merchant licenses and production quotas allocated by the national Forest Service, and permits for woodcutting and transport that could only be obtained by licensed merchants with quotas (Ribot 1999a). ${ }^{26}$ The licenses are allocated to powerful merchants by the Director of the National Forest Service and Minister of Environment.

Each year, the Forest Service and ministry for environment fixed a national quota for charcoal production and allocated it among some 120 to 170 enterprisescooperatives, economic interest groups and corporations-holding professional forest producer licenses delivered by the Forest Service. They promulgated an annual decree listing the quota for each enterprise and indicating the forested region, Tambacounda or Kolda, where these quotas were to be exploited. Soon after, each Regional Forest Services would inform the recipients, mostly urbanbased merchants, of the villages where they would be allowed to exploit their charcoal quotas. There was no local say in the matter.

With a charcoal quota in hand, a charcoal merchant could then hire migrant laborers (most from neighboring Guinea), obtain woodcutting permits for the migrants from the local forestry brigade office, bring their migrant laborers to a village, and negotiate with the village chief to house them during tree cutting and carbonization. After production the merchant would come to pick up the charcoal. Most migrants could produce two truckloads per year of about 300-400 sacks. For each truckload, the merchant would pay the migrant workers in the forest, load the truck, and pay taxes to obtain a transport permit at the local forestry brigade office. With this permit they could transport their charcoal to market in Dakar. Through this system the merchants controlled the market.

\section{The forestry sector after decentralization}

Senegal's 1996 Decentralization Law (RdS 1996b) transferred natural-resource management, among other powers, to elected 'rural councils'. The 1996 decentralization law gave rural councils jurisdiction over "the organization of exploitation of all gathered plant products and the cutting of wood" (RdS 1996b:art.195). Another 1996 decentralization law, specifying the transfer of specific powers, gave the rural council jurisdiction over "management of forests on the basis of a management plan approved by the competent state authority" (RdS 1996a:art.30).

The 1998 forestry code (RdS 1998) conformed with the 1996 decentralization reforms by recognizing rural councils' rights to determine who will have the right

\footnotetext{
25 Charcoal production in Senegal is believed by donors and by Senegal's Forest Service to be highly destructive to forests. The evidence, however, is slim. See Ribot 1999a.

${ }^{26}$ Based on the 1993 forestry code and similar codes dating back to 1935 .
} 
to produce in these forests (art.L8,R21). The new forestry code also defined community forests, stating that "Community Forests are those forests situated outside of the forested domain of the State and included within the administrative boundaries of the rural community who is the manager" (RdS 1998:art.R9). The forested domain of the state consists of areas reserved for special uses and protection (RdS 1998:R2), and most of Senegal's forests are not reserved. In short, the new laws give most rural communities control over large portions of the forests - if not all of the forests — within their territorial boundaries.

As an added protection of these new rural-community rights, the forestry code requires the Forest Service to obtain the signature of the rural council president (PCR, elected from among the rural councilors) before any commercial production can take place in their forests (RdS 1998:art.L4). This radical decentralized and democratic 1998 forestry code and the 1996 decentralization laws changed everything - at least on paper. The powers of all actors changedforesters, councilors, and merchants. Rather than the Forest Service allocating access to urban merchants, the rural council would choose the merchants it wanted working in its forests. Rather than the Forest Service managing the forests, management is now the role of the rural council. Rather than receiving their quota from the Forest Service and exploiting it, the merchants now had to go to the councils for permission to exploit, and the amount they could exploit was to be determined by the ecological potential of the forest in a management plan approved by the PCR and Forest Service.

\section{Repertoires of Domination: Maintaining Senegal's old forestry regime after reform}

Rural councilors were very excited to gain control over rural community forests. They wanted to stop merchants and their migrant laborers from cutting the forests out from under them. They also wanted forest villagers to have opportunities to exploit the forests themselves to bring income into the villages and revenues to the rural council. Decentralization gave these powers to the rural councils. Exercising these new rights would have also helped the councils to build a role in the community and gain some local legitimacy. But, despite the reforms, little has changed in practice. Few powers have been transferred. Councilors claim that they still have nothing to offer their populations. They have attempted to exercise their new powers, but have been blocked at every step. This section explores the repertoire of domination used by Senegal's Forest Service, prefects, and merchants to maintain the status quo-depriving the new elected rural councils of their new powers and roles.

The decentralization and new forestry laws should apply equally to all zones of Senegal. But, the Forest Service applies them differently in areas with donor projects than in non-project areas. In non-project/non-managed areas, exploitation continues to take place, illegally, through quotas and permits as in the period before the 1998 law-the only difference is that rural council presidents in these areas have been forced to sign off before exploitation began 
each year (Ribot 2009b). In donor project areas, however, forest villagers have been allowed to reap significant benefits. Donors and foresters hold up the villagers' profits as a great success. But it is a qualified success. When compared to what these forest villagers 'could' gain and compared to what merchants are gaining -in the project and in the non-managed areas-their success appears anemic. The image of success depends on how it is presented and performed (Baviskar 2007). This section describes the difficulties faced by villagers in project areas who tried to profit from charcoal.

Hoping to increase village income, the World Bank's PROGEDE project began in 1998 to train forest villagers to produce and sell their own charcoal. Until 1998, the quota system gave the Forest Service total control over market accesswhich it allocated to licensed merchants. The licenses help the merchants maintain a tight oligopsony on forestry markets. The law of the liberalization of the professions (RdS 1995), however, was supposed to have eliminated these (and most other) licenses-but the Forest Service continued licensing, despite the law. In the first years of project production, forest villagers (like migrant laborers before them) had to sell their charcoal to licensed quota-toting merchants for a subsistence wage at the forest edge. The 1998 forestry code specified that the quota system would be eliminated in 2001. But, the quota system was not eliminated. Despite talk of village participation and marketing of charcoal, the Forest Service refused to give quotas to forest villagers (or to the projects). Forest villagers were forced to continue to sell at the forest edge-they could not take their charcoal to Dakar. It was not until 2006 that the first truckload of charcoal produced under PROGEDE was sold by forest villagers at a significant profit in Dakar (personal communication, project director, 2006).

How did the Forest Service delay transfer? How did they reduce it to only a few truckloads per year out of 7000 ? First, the Forest Service took several years to elaborate forest management plans (which they began developing well before 1998). While described as a means to protect the forests, these management plans have virtually no ecological function (Wurster 2010; Ribot 1999b). They then took time to train forest villagers to produce charcoal. While described by the Forest Service as necessary training, the villagers do not need training in charcoal production since they usually hire expert migrant charcoal makers to do the work (interviews 2003-9; Ribot 1999b). 27 During plan development and training time, foresters consistently refused to let the project participants sell charcoal to anyone but licensed merchants with quotas. The PROGEDE project, and later USAID's Wula Nafaa project, repeatedly asked the Forest Service for charcoal quotas for their project villages. But they were turned down on the grounds that the villagers lacked capacity to market their products or that marketing was only for the quota-holding licensed merchants-despite that quotas and licenses were eliminated by law.

\footnotetext{
${ }^{27}$ Fulbe 'experts' build traditional kilns. The Forest Service requires a new 'improved' kiln they claim is more efficient. Charcoal producers disagree and there is no evidence to this effect (Ribot 1999b).
} 
In 2005, while still allocating quotas to merchants, the Forest Service agreed to establish contracts between project rural communities, the Forest Service and merchants. Under these contracts the merchants agreed to buy village-produced charcoal. The contracts fixed the forest-edge price (the producer price in the forest) and included a fee to feed a forest-management fund managed by the forestry union, the Forest Service and rural council (leaving it ambiguous as to who can decide to spend it when). Under these contracts, the (illegally-RdS 1995) licensed merchants were enabled to obtain permits (still not directly accessible to villagers) to transport the villagers' charcoal. The 'contracts' were effectively 'quotas' with a new name. They gave merchants a quantity of charcoal they could transport to Dakar (enabling them to rent out their trucks). They also kept villagers dependent on the merchants (and merchants dependent on foresters) for marketing rights.

Forest villages were not at all happy with the low price of $\$ 1.50$ per sack they were getting from merchants at the forest edge. They wanted their own transport permits so they could sell in Dakar where the price per sack was usually \$10-14. The two projects continued asking the Forest Service for production quotas (despite the quota's illegal status) or contracts to allow circulation to Dakar so that the project villages could market their own charcoal. But, the Forest Service argued that rural communities 'lack the capacity' to produce marketable quantities and do not know the markets - this is patently absurd since each villager can produce as much as a professional migrant and knowing the market merely requires finding one of many willing buyers. The PROGEDE project insisted, complaining to the Forest Service Director and the minister responsible for environment.

In 2006 the Forest Service Director asked a merchant who was 'contracted' to purchase project charcoal to help the villagers to sell to wholesalers in Dakar. So, rather than getting their own quota or an independent contract, the project villagers took their first truck to Dakar under contract with a licensed merchant. In Dakar the villagers sold their charcoal at $\$ 11$ per sack. They paid $\$ 3$ per sack for transport and $\$ 100$, or about $33 \phi$ per sack, for bribes to foresters and police along the road, thus netting $\$ 7.66$ per sack (much more than the $\$ 1.50$ per sack they were getting in the forest). So, rather than earning just $\$ 450$ per truckload of 300 sacks (the product of four to six months of labor by one producer), by selling in Dakar they took home $\$ 2300$. They quintupled their income with just an additional 3 to 5 days of the easy labor to take the charcoal to sell in Dakar. This was a great success for the villagers and PROGEDE. The USAID project followed suit shortly after-using contracts with merchants to help villagers market their charcoal.

The villagers who went with the first truckloads to Dakar were delighted by the remarkable amount of money they made. 28 When they returned home with the

28 The story of the first truckload of charcoal is told in the film Semiñ Nari Bor, Ribot (2010 forthcoming). 
money, as one villager said, "the whole village was so happy we danced all night and forgot to eat." But, they were also angry that they had been robbed for so long. For every truckload they were selling at the forest edge for $\$ 450$, the licensed merchants were making almost $\$ 1850$ in clear profit (about $\$ 2300$ in net income after transport and bribes minus the producer price). While an individual woodcutter can produce two truckloads of charcoal a year, each merchant was liberally allocated quotas for between ten and fifty truckloads a year-merchants were making astounding profit with little work. Once the villagers saw the profits, they wanted to sell all their charcoal in Dakar. But they were systematically blocked by the Forest Service. The projects asked for contracts allowing more production and transport to Dakar, but they were still told they could only have several truckloads a year until villagers showed that they had the 'capacity' to market the truckloads they were allocated.

As of June 2009, forest villagers in dozens of World Bank and USAID project villages in the managed areas get to take a total of about 80 truckloads per year to Dakar under contracts for charcoal production, while the other 7,000 truckloads that are sold in Dakar are still sold by the merchants. Forest villagers are earning a fragment of what they could make if the current laws were upheld by the Forest Service.

The Forest Service insists that local people have no capacity. In addition, the foresters insist that twenty-year management plans, once signed by the PCR, take the place of the PCRs' right to approve each year's production. Foresters use the management plans, contrary to PCR understanding, to override or take away the PCRs rights to sign off before production can take place each year. Foresters also act like there are no rights without a management plan-despite that, even without management plans, the law requires the rural council president's signature ('signature préalable') before any forest production can take place. The foresters and the sub-prefects and merchants all just act as if their way of doing things is legal. Contrary to the new laws, the foresters and subprefects also frequently remind the councils that 'forests are for everyone', 'they are a national and global good', the role of the rural council is not to determine what their use shall be, but to manage the forests for the use of others.

In March 2009, the minister of environment circulated a decree to eliminate the (already illegal) quota system on 1 January 2010. The quota will now be replaced by 'contracts'-quotas under a new name. This ministerial decree was written in response to a conditionality on a $\$ 60$ million loan from the World Bank. Colleagues at the World Bank and USAID expressed their delight with this change. Forester and donor alike act as if this is a great victory, as if a long awaited reform has come. But the quota was eliminated in 1998. Ministers before the current minister promised to eliminate it many times before. This time they 
have eliminated it. The quota is dead, long live the contract. The 'contract' is now being written into a proposed forestry law-nothing is changing (Ribot 2009a). ${ }^{29}$

The director of the Forest Service, in his role as defender of the environment, still insists that a quota or something equivalent is needed to protect the forests.

When he is shown that the quantities allocated in the quota system are far below current consumption, he insists that quotas are needed to limit production to the ecological capacity of the forests. When he is shown that the quotas and contracts are not calculated based on the ecological capacity of forests, he goes back to insisting it is set to limit consumption. It is like a shell game where the only shell is imagination. Somehow, the imagined ecological importance of quotas or contract is more powerful than its obvious lack of ecological function and its clear political and economic roles. The quotas (and 'contracts') are means for capturing the markets. Like with capacity arguments, transparent absurdity seems to play no role in undermining arguments in service of power.

Dominance is maintained by the Forest Service through a repertoire of discursive performances (see Ribot 2009b; Ribot and Oyono 2005). New laws are transgressed or not implemented with the support of discourses of ecological necessity in a fragile environment, insistence that policies with no ecological functions reduce consumption or protect trees, repetition of stock phrases about villagers lacking capacity to manage forests or to make and sell charcoal, implausible and shameless reinterpretation of policies, use against rural people of arguments that forests are 'for the nation as a whole'-are all part of the repertoire of domination in Senegal's forest sector. While there are small advances taking place, the success of some forest villagers profiting from charcoal sale is held up in order to distract attention from the widespread continued urban-merchant exploitation of what should now be the forests of rural communities. Success - ten truckloads in a thousand-is performed to hide continuity of an ongoing extractive regime. Foresters and merchants, with support of prefects and donors, build a discursive wall of ecology and capacity between forest villagers and lucrative forest markets.

\section{Conclusion: Repertoires of Domination and of Resistance}

This article explored how wildlife managers, foresters, politicians and merchants in Botswana and Senegal used repertoires of domination to gain, consolidate and maintain power in the face of new laws and movements for decentralizing natural resource management and use. The article develops and illustrates the use of

\footnotetext{
${ }^{29}$ Ribot (2009a) critiqued the new draft new forestry code for Senegal, pointing out how it will further undermine forestry decentralization and local democracy. It continues to support illegal licenses and replaces quotas with contracts. The USAID contractors who commissioned this critique did not translate it into French, despite an earlier agreement to do so, stating that "it is too long, too repetitive, some of the points have already been taken up by Wula Nafaa [their project] with the task force and some of his points were not accepted by the Wula Nafaa team ([names removed]). Overall, however, the report raises some good points that we will push for in the new code" (no names, November 2009). The result is that there will be no public debate - because the USAID project personnel do not want any debate. They know best.
} 
the 'repertoires of domination' framing, drawing three interlinked points from the case studies on: 1) the nature of repertoires; 2) the plurality of power; and 3) decentralization and democratization as ongoing processes of stratification. We briefly elaborate these points and conclude below.

\section{The Nature of Repertoire}

The term 'repertoire' draws attention to three key features of the struggle for power: the availability of multiple performances, the possibility of improvisation and other forms of creativity, and differences in the quality of performance. A repertoire refers to the set of routine claim-making actions available to actors as they compete for power. A repertoire, by definition, includes multiple performances. Repertoires are not fixed. They may change in response to opportunities, but also as actors creatively expand their repertoires. Actors regularly improvise within otherwise familiar performances; improvisation can also generate important innovations (Tilly 1978, 2006, 2008). Transposition-in which actors transfer performances across types of relationships or settings-is another common and important form of creativity (compare Bourdieu 1977, 8283; Sewell 1992, 17-18). Thus, repertoires offer considerable-albeit not totalflexibility. The act on stage is only one of many possible acts and ending one performance to promote more effective decentralization will not put the theatre of domination out of business.

Performative skill, both in terms of creativity and in the quality of performance, varies across actors and acts (Alexander and Mast 2006). Although we have given relatively little attention to differences in the quality of performance in this article, they can greatly influence the effectiveness of particular performances and the dynamics of contestation. Arguably, continuing with the theatrical metaphor, rehearsal can raise the quality of performance. We return to this point below. But first we consider the connections between repertoires and performance and power. We argue that background conditions of power influence both the richness of repertoires and the quality of particular performances.

\section{The Plurality of Power}

Repertoires include multiple performances because they draw on multiple forms of power-political, economic, discursive, coercive, symbolic and material. These powers may be located in things, symbols, individuals, institutions, relations, or in the contours of discourse. Actors who are striving for domination (like all other actors) have access to bundles of powers (Ghani 1996). The strands in these bundles may be employed in combinations or one by one. We have seen combinations of discursive and material power, as when actors controlling access to markets justify their claims or use normatively laden discourse to communicate threats or promises. Likewise, officials use administrative power to control material opportunities. Practices must be observed with an eye to all forms that power can take. 
The plurality of power implies that no single theory of power is sufficient to generate knowledge of the range of acts that are being used in a repertoire of domination. Different theories prioritize one or another source of power, based on assumptions about the ultimate sources of power and the mechanisms through which power operates. In practice (which is where performance takes place), different forms of power coexist—regardless of epistemological irreconcilability. ${ }^{30}$ People draw opportunistically on powers that fit different theories even if those theories consider themselves to be incompatible. Hence, counter-actors as well as analysts would do well to be aware of multiple theories and forms of powerto recognize the many different acts in play.

\section{Decentralization as Process}

Neither decentralization nor democratization is simply aimed at and achieved once and for all. Decentralization and centralization, democratization and dedemocratization, are iterative, contested, ongoing processes. Spaces of local autonomy are constantly being carved out, re-enclosed, and reopened.

Domination is constantly being enacted, as is resistance. When challenged, powerful actors can usually sidestep attempts to end their act by drawing upon other performances in their repertoires. We have focused on repertoires of domination, but recognize that repertoires of resistance are also well rehearsed and constantly enacted.

Important changes do happen. Some produce new spaces of local autonomy. For example, the powers of rural councils in Senegal were expanded under decentralization. They gained the power to sign off on the opening of the charcoal production season. While their exercise of this power has been largely blocked, in the areas where USAID and the World Bank have tried to protect local interests, tax and fine revenue from charcoal has gone up and rural populations have seen an increase in income. In Botswana, CBOs gained discretionary sources of revenue that empowered them to pursue local priorities that had been overlooked by the government. These initiatives ranged from the construction of orphanages and the provision of drinking water to subsidies for small-scale enterprises. CBNRM also greatly empowers local communities in their dealings with safari companies and makes the worst forms of exploitation less likely. The partial recentralization of CBNRM in 2007 represents a major loss, but not a complete reversal.

These successes are tempered. Decentralization achieved only a fraction of the autonomy promised in discourse and law. Equally importantly, the changes were not unidirectional. In each case, the empowerment of local communities was attenuated by the antics of powerful actors. In Botswana, CBNRM offered opportunities for the wildlife department and the Land Board to expand their authority vis-à-vis other government agencies as well as the CBOs. In Senegal, villagers in the project areas depend on the donors, the Forest Service and

\footnotetext{
30 Compare Schneider and Ingram's (1990) analysis of the diverse behavioral assumptions underlying policy tools.
} 
merchants to gain access to urban charcoal markets. Both countries introduced subsequent policies and regulations that further reduced the scope for local autonomy.

Stratification is a constant process. Given the constant impulse for domination, what can be done to realize more fully the democratizing potential of decentralization? The extent to which the democratizing potential of decentralization is realized depends on the depth and effective use of repertoires of resistance. Peluso (1992) points out that local resistance to state forestry responds to-even parallels - the mechanisms the state uses to exercise control over the forests. Scott has shown how everyday acts of foot dragging, sabotage and withdrawal serve as the weapons of the weak (Scott 1985). Weapons of the weak erode and limit domination, but they represent the limited options available to-or perceived by-the weak. Empowerment requires informed and effective repertoires of resistance. Indeed, it implies capture of repertoires of domination as well-which is also why stratification is a constant process.

Decentralization reforms are often launched with programs ('accompanying measures') to inform the population and new elected officials of their powers and rights. Being informed requires investigation and critical analysis, and not just a presentation of the laws as they are written. Local residents and their leaders will be better able to claim new powers if they recognize the ways in which their rights are subtly and/or brutally being attenuated. Of course, local actors are usually aware of abuses and can do little about it. While it is unlikely that repertoires of domination will be countered effectively if they are not recognized, awareness of them will not produce empowerment on its own. Empowerment is a constant process of leveraging existing sources of power more effectively and developing new sources of power.

The density and vitality of voluntary organizations—variously labeled as civil society or social capital-are widely touted as conditions for empowerment (Lipset 1959; Putnam 1993). Organization-into unions, federations, or networks - can facilitate information exchange, learning across localities, and coordinated action. Non-local allies can help create and expand the space for local organizations to operate (e.g., Heller 2001). Examples include Botswana's CBNRM Support network, sponsored by SNV and IUCN, and the Democratie et Gouvernance Locale (DGL) project, financed by USAID, in Senegal. NGOs, donors, and allies in government can provide critical support to local-level efforts to claim their rights through political pressure, courts or direct action. Efforts also include research and research articles such as this one, and the dissemination of research results through popular channels, such as policy briefs, popular articles and films. ${ }^{31}$

\footnotetext{
31 Search vimeo.com for Semmiñ Naari Boor by Ribot (2010 forthcoming) for a film dramatizing the story of the above Senegal case.
} 
Ultimately, however, we return to two central observations: (1) decentralization and centralization, and democratization and de-democratization, are on-going processes, and (2) repertoires of domination and resistance enable on-going contestation of these shifts in power. Consequently, there is no single, once-andfor-all recipe for successful decentralization or democratization. We have shown that it is not enough to activate processes of decentralization and democratization, because any reallocation of authority will be contested. To sustain these processes of decentralization and democratization requires the development and ongoing renewal of repertoires of resistance to pervasive centrifugal pressures.

\section{Works Cited}

Agrawal, A. \& Gibson, C. C. (1999). Enchantment and Disenchantment: The Role of Community in Natural Resource Conservation. World Development, 27(4), 629649.

Agrawal, A. \& Ostrom, E. (2001). Collective Action, Property Rights, and Decentralization in Resource Use in India and Nepal. Politics and Society, 29 (4), $485-514$.

Agrawal, A. \& Ribot, J. C. (1999). Accountability in Decentralization: A Framework with South Asian and West African Cases. Journal of Developing Areas, 33 (4), 473-502.

Alden Wily, L. \& Mbaya, S. (2001). Land, People and Forests in Eastern and Southern Africa at the Beginning of the $21^{\text {st }}$ Century. The Impact of Land Relations on the Role of Communities in Forest Future. Nairobi: IUCN East Africa Regional Office.

Alexander, J. C. \& Mast, J. L. (2006). Introduction: Symbolic Action in Theory and Practice: The Cultural Pragmatics of Symbolic Action. In J. C. Alexander, B. Giesen, \& J. L. Mast (Eds.), Social Performance: Symbolic Action, Cultural Pragmatics, and Ritual (pp. 1 -28). New York: Cambridge University Press.

ARCA Consulting. (2000). Botswana Tourism Master Plan: Final Report. Gaborone, Botswana: Department of Tourism, Ministry of Commerce and Industry, Republic of Botswana.

Barrow, E., Gichohi, H. \& Infield, M. (2001). The Evolution of Community Conservation Policy and Practice in East Africa. In D. Hulme \& M. Murphree (Eds.), African Wildlife and Livelihoods: The Promise and Performance of Community Conservation (pp. 59 - 73). Oxford: James Currey.

Bates, R. H. (1983). Essays on the Political Economy of Rural Africa. Berkeley: University of California Press.

Bazaara, N. 2006. Subjecting Nature to Central Authority: The Struggle over Public Goods in the Formation of Citizenship. Africa Development, XXXI(2), 19 - 36.

Blaikie, P. (2006). Is Small Really Beautiful? Community-based Natural Resource Management in Malawi and Botswana. World Development, 34 (11), 1942-1957.

Blair, H. (2000). Participation and Accountability at the Periphery: Democratic Local Governance in Six Countries. World Development, 28 (1), 21-39. 
Boggs, L. P. (2004). Community Based Natural Resource Management in the Okavango Delta. In C. Fabricius, E. Koch, H. Mogome, \& S. Turner, eds., Rights, Resources and Rural Development: Community Based Natural Resource Management in Southern Africa (pp. 147 - 159). London: Earthscan.

Bolaane, M. (2004). The Impact of Game Reserve Policy on the River BaSarwa/Bushmen of Botswana. Social Policy and Administration, 38 (4), 399417.

BOPA. (2007a). Audit Report Shows Abuse of Khwai Trust Funds. Botswana Daily News Online (27 February 2007). http://www.gov.bw/cgibin/news.cgi?d=20070227. Accessed 27 April 2007.

BOPA. (2007b). Trust Should Benefit Community. Botswana Daily News Online (28 February 2007). http://www.gov.bw/cgi-bin/news.cgi?d=20070228. Accessed 27 April 2007.

Bourdieu, P. (1977). Outline of a Theory of Practice. New York: Cambridge University Press.

Cassidy, L. (2000). CBNRM and Legal Rights to Resources in Botswana. CBNRM Support Programme Occasional Paper No. 4. Gaborone: IUCN/SNV CBNRM Support Programme.

Crook, R. C. \& Manor, J. (1998). Democracy and Decentralization in South Asia and West Africa: Participation, Accountability and Performance. New York: Cambridge University Press.

Flyman, M. V. (2001). Living for Tomorrow in Southern Kalahari. In N. Rozemeijer (Ed.), Community-Based Tourism in Botswana: The SNV Experience in Three Community-Tourism Projects (pp. 47 - 58). Gaborone: SNV Botswana and SNV Service and Mediation Department in cooperation with SNV Information Department.

Foucault, M. (1979). Discipline and Punish: The Birth of the Prison. Sheridan, A. (Trans.). New York: Vintage Books.

Foucault, M. (1976). The History of Sexuality Vol. 1: The Will to Knowledge. London: Penguin.

Fung, A. \& Wright, E. O. (Eds.) (2003a). Deepening Democracy: Innovations in Empowered Participatory Governance. New York: Verso.

Fung, A. \& Wright, E. O. (2003b). Thinking about Empowered Participatory Governance. In A. Fung \& E. O. Wright (Eds.), Deepening Democracy: Innovations in Empowered Participatory Governance (pp. 3 -42). New York: Verso.

GEF Small Grants Program. (2006). Strengthening Community Participation in EcoTourism: A Contribution towards Rehabilitation of Tsaro Lodge, A Khwai Development Trust Initiative. (BOT/OP3/2/07/01). Community Action, Global Impact. GEF and UNDP.

http://sgp.undp.org/web/projects/11655/strengthening_community_participation_i n_eco_tourism_a_contribution_towards_rehabilitation_of_tsaro_.html.

Ghani, A. (1995). Production and Reproduction of Property as a Bundle of Powers: Afghanistan 1774-1901. Draft discussion paper in Agrarian Studies Program. New Haven: Yale University. 
Gibson, C.C. \& Marks, S. A. (1995). Turning Hunters into Conservationists: An Assessment of Community-Based Wildlife Programs in Africa. World Development, 23(6), 941-957.

Gujadhur, T. \& C. Motshubi. (2001). Among the Real People in /Xai-/Xai. In N. Rozemeijer (Ed.), Community-Based Tourism in Botswana: The SNV Experience in Three Community-Tourism Projects (pp. 21-33). Gaborone: SNV Botswana and SNV Service and Mediation Department in cooperation with SNV Information Department.

Heller, P. 2001. Moving the State: The Politics of Democratic Decentralization in Kerala, South Africa, and Porto Alegre. Politics \& Society, 29(1), 131-163.

Hooghe, L. \& Marks, G. (2003). Unraveling the Central State, but How? Types of Multilevel Governance. American Political Science Review, 97 (2), 233-243.

Hulme, D. \& Murphree, M. (Eds.) (2001). African Wildlife and Livelihoods: The Promise and Performance of Community Conservation. Oxford: James Currey.

Larson, A. M. \& Ribot, J. C. 2007. The Poverty of Forestry Policy: Double Standards on an Uneven Playing Field. Sustainability Science, 2(2), 189-204.

Lipset, S. M. (1959). Some Requisites of Democracy. American Political Science Review, 52 (1), 69-105.

Lund, C. (2006). Twilight Institutions: Public Authority and Local Politics in Africa. Development and Change, 37 (4), 685-705.

Mamdani, M. (1996). Citizen and Subject: Contemporary Africa and the Legacy of Late Colonialism. Princeton: Princeton University Press.

Manor, J. (2004). User Committees: A Potentially Damaging Second Wave of Decentralisation? European Journal of Development Research, 16(1), 192-213.

Mbaiwa, J. E. (2005a). The Problems and Prospects of Sustainable Tourism Development in the Okavango Delta, Botswana. Journal of Sustainable Tourism, 13(3), 203277.

Mbaiwa, J. E. (2005b). Wildlife Resource Utilisation at Moremi Game Reserve and Khwai Community Area in the Okavango Delta, Botswana. Journal of Environmental Management, 77(2), 144-156.

Mitchell, T. (1991). The Limits of the State: Beyond Statist Approaches and their Critics. American Political Science Review, 85(1), 77-96.

National CBNRM Forum. (2003). Proceedings of the Fourth National CBNRM Forum meeting in Gaborone, Botswana, $12^{\text {th }}$ of June 2003. Gaborone: CBNRM Support Programme.

Ntuane, B. (2007a). CBNRM Policy Undermines Mogae's Ethos Of Collective Ownership During its August sitting, Parliament endorsed the Community Based Natural Resources Management Policy. Mmegi Online, Vol. 24, No. 136 (10 September 2007). http://www.mmegi.bw/2007/September/Monday10/57.php. Accessed 2 January 2008.

Ntuane, B. (2007b). The Good and Bad: 100 Villages versus CBNRM Policy. Mmegi Online, Vol. 24, No. 144 (24 September 2007). http://www.mmegi.bw/2007/September/Monday24/85.php. Accessed 2 January 2008.

O'Neill, K. (2003). Decentralization as an Electoral Strategy. Comparative Political Studies, 36(9), 1068-1091. 
Peluso, N. L. (1992). Rich Forests, Poor People: Resource Control and Resistance in Java. Berkeley: University of California Press.

Poteete, A. R. (2009). Defining Political Community and Rights to Natural Resources: The Case of Community-Based Natural Resource Management in Botswana. Development and Change, 40(2), 281-305.

Putnam, R. D. (1993). Making Democracy Work: Civic Tradition in Modern Italy. Princeton, NJ: Princeton University Press.

Ramsden, F. J. (2006). .Keynote Address. Delivered at the Community Based Natural Resource Management Workshop organized by the Directorate on Corruption and Economic Crime in Maun, Botswana, 6 December 2006. The Ministry of Works and Transport, Government of Botswana, website http://www.mwt.gov.bw/index.php?sectid=193\&articleid=1108. Accessed 27 April 2007.

Republic of Botswana. (2007). Government Paper No. 2 of 2007: Community Based Natural Resources Management Policy. Gaborone: Botswana Government Printer.

Republic of Botswana. (1986). Government Paper No. 1 of 1986: Wildlife Conservation Policy. Gaborone: Botswana Government Printer.

RdS - République du Sénégal (1998) Code Forestier. Loi no. 98/03 du 08 janvier 1998 et Décret no. 98/164 du 20 février 1998. République du Sénégal, Ministere de l'environnement et de la protection de la nature, direction des Eaux, Forets, Chasse et de la Conservation des Sols.

RdS (1996a) Loi portant transfert de compétences aux régions aux communes et aux communautés rurales. République du Sénégal, Dakar 22 mars.

RdS (1996b) Loi Portant Code des Collectivités Locales. République du Sénégal, Dakar 22 mars.

RdS. (1995) Décret 95-132 du $1^{\circ}$ février 1995 (RdS 1995) «portant libéralisation de l'accès à certaines professions », République du Sénégal.

Ribot, J. C. (2010 forthcoming). Semiñ N ari Bor. http://www.vimeo.com/.

Ribot, J. C. (2009a). Analysis of Senegal's Draft Forestry Code: With Special Attention to its Support for Decentralization Laws. Report to USAID's Wula Nafaa Project. November 2009.

Ribot, J. C. (2009b). Authority over Forests: Empowerment and Subordination in Senegal's Democratic Decentralization. Development and Change, 40(1), 105129.

Ribot, J. C. (2004). Waiting for Democracy: The Politics of Choice in Natural Resource Decentralizations. Washington, DC: World Resources Institute.

Ribot, J. C. (1999a). Decentralization and participation in Sahelian forestry: legal instruments of central political-administrative control. Africa, 69(1), 23-63.

Ribot, J.C. (1999b). A History of Fear: Imagining Deforestation in the West African Sahel. Global Ecology and Biogeography, 8(3), 291-300.

Ribot, J. C., Agrawal, A., \& Larson, A. M. (2006). Recentralizing while Decentralizing: How National Governments Reappropriate Forest Resources. World Development, 34(11), 1864-1886. 
Ribot, J. C., Chhatre, A., \& Lankina, T. (2008). Introduction: Institutional Choice and Recognition in the Formation and Consolidation of Local Democracy.

Conservation and Society, 6(1), 1-11.

Ribot, J. C. \& Oyono, R. (2005). The Politics of Decentralization. In Ben Wisner, Camila Toulmin and Rutendo Chitiga eds., Toward a New Map of Africa. London: Earthscan Press.

Ribot, J. C. \& Peluso, N. L. (2003). A Theory of Access. Rural Sociology, 68(2): 153181.

Salvatore, R. D. (2000). Repertoires of Coercion and Market Culture in NineteenthCentury Buenos Aires Province. International Review of Social History, 45 409448.

Schneider, A. \& Ingram, H. (1990). Behavioral Assumptions of Policy Tools. Journal of Politics, 52(2), 510-529.

Scott, J. C. (1985). Weapons of the Weak. New Haven: Yale University Press.

Sewell, W. H., Jr. (1992). A Theory of Structure: Duality, Agency, and Transformation. American Journal of Sociology, 98(1), 1-29.

Stevens, P. W. \& Jansen, R. (2002). Botswana National Ecotourism Strategy. Gaborone, Botswana: Government of Botswana.

Taylor, M. (2002). The Shaping of San Livelihood Strategies: Government Policy and Popular Values. Development and Change, 33(3) 467-488.

Taylor, M. (2000). Life, Land and Power: Contesting Development in Northern Botswana. Ph.D. dissertation, University of Edinburgh.

Tarrow, S. (2008). Charles Tilly and the Practice of Contentious Politics. Social Movement Studies, 7(3), 225-246.

Thakadu, O. T. (2005). Success Factors in Community Based Natural Resources Management in Northern Botswana: Lessons from Practice. Natural Resources Forum, 29(3), 199-212.

Tilly, C. (2008). Contentious Performances. New York: Cambridge University Press.

Tilly, C. (2006). Regimes and Repertoires. Chicago: The University of Chicago Press.

Tilly, C. (1978). From Mobilization to Revolution. New York: McGraw-Hill Publishing Company.

Twyman, C. (2001). Natural Resource Use and Livelihoods in Botswana's Wildlife Management Areas. Applied Geography, 21(1), 45-68.

Wittayapak, C. \& Vandergeest, P. (Eds). (2009). The Politics of Decentralization:

Natural Resource Management in Asia. Chiang Mai: Mekong Press.

Wunsch, J. S. (2001). Decentralization, Local Governance and 'Recentralization' in Africa. Public Administration and Development, 21(4) 277-288.

Wurster, K. (2010). "Does Management Matter? Assessing the Effects of Charcoal Production and Management on Woodland Regeneration in Senegal." Ph.D. dissertation, Department of Geography, University of Maryland. 